\title{
DEVELOPMENT OF CORPORATE GOVERNANCE IN THE CONTEXT OF GLOBALIZATION OF INTERNATIONAL BUSINESS
}

\begin{abstract}
Olga Sunigovets ${ }^{1}$
${ }^{1} \mathrm{PhD}$ (Economics), Associate Professor, Associate Professor of the Department of Management of Innovative Entrepreneurship and International Economic Relations, National Technical University "Kharkiv Polytechnic Institute», Kharkiv, Ukraine, e-mail: oms.ukr.kpi@gmail.com, ORCID: https://orcid.org/00000003-1623-5798
\end{abstract}

Successfully managed companies achieve high results in the long run, have access to capital. High management standards reduce investment risk. One of the most pressing problems of business research is the problem of corporate governance. Improvement and development of corporate governance mechanisms are important primarily for large business structures. Improving the efficiency of integration interaction of enterprises will allow them to meet the global challenges of the world market, ensure their competitiveness and efficiency. The problems of corporate governance are inextricably linked with such major processes as increasing globalization of the world economy, increasing competition in industries, increasing the role of private companies in the economy, which causes increased interest in the study of corporate governance.

Long-term success of companies at the global level is impossible without improving the quality of corporate governance. The corporate governance system covers a number of strategic aspects, the solution of which determines the organizational efficiency of the company. The construction of the corporate governance system is determined in terms of its constituent elements and their quality, the practice of corporate governance must meet the requirements of modern world development trends, the best examples of global achievements in corporate governance. Corporate governance contributes to the competitiveness of companies.

Corporations are the basis for the development of economically developed countries, the successful operation of the corporate sector has brought Western countries to the forefront in the world. Integration processes are an integral part of the world economy.

In economically developed countries, the economy of corporations dominates, the economy of intersectoral vertical integration in the context of developing integration processes.

Theoretical and methodological foundations of integration processes, the development of principles for determining the effectiveness of vertically integrated structures are the interests of scientists P. Joscoe, J. Stacky, A. Strickland, A. Thompson, O. Hart. The effectiveness of the corporate governance system is studied by A. Burley, J. M. Keynes, J. Lamben, W. Oiken, P. Drucker [1], M. Porter, P. 
Samuelson, E. Chamberlin and others. These studies were continued by foreign scientists I. Ansoff, W. Butner, D. Meyer, B. Maine, D. Sailer, D. Sullivan, D. Tobin, M. Hessel and others.

Synergetic effects can create corporate relationships both in the form of competition and in the form of cooperation. Effective corporate governance should promote a common focus of interests of all participants in corporate relations. The principle of corporatism provides a single vector of interests, harmony and nonviolation of interests. Corporate legislation, corporate culture, corporate governance in Ukraine are at the stage of formation.

The key elements of good corporate governance are developed on the basis of generalization of the experience accumulated in world practice and are described in the principles of corporate governance of the OECD, which are actively implemented in the domestic practice of corporate governance. Current trends in the globalization of economic processes, the active development of integration processes, corporate governance in Ukraine determine the need for more objective consideration of the functioning of economic systems, research of corporate governance, improving the quality of corporate governance to world standards.

Corporate relations and their impact on innovative development in the context of globalization of international business. In the context of global destabilization of the economy, strategic uncertainty of corporations, the innovative direction of development, changes in the organization and management of economic processes are studied, the ability to produce goods and services is associated with indicators of innovation, innovative activity, quality of life, quality of corporate governance. Innovative economy is a type of economy in which the accumulated knowledge provides the generation of innovations that meet the dynamically changing needs of society. The concept of innovative economy, formulated by the OECD (Organization for Economic Cooperation and Development), is based on the principles of flexibility, adaptation to changing conditions of development.

The main factor of economic stability in general and economic structures are knowledge and information, which is the basis of innovation, new technologies. At the present stage of development, the role of corporations as a major participant in economic development, internal and external economic relations is growing. Attention is paid to corporate governance systems, features and patterns of corporate growth, contradictions of economic interests of industrial business corporations. For modern business in an innovative economy, the corporation is the most capable institution, as one that has financial, organizational and technological, intellectual capabilities and resource potential.

The problems of systemic development of corporations, due to increasing competition and the introduction of institutional mechanisms, are real. The issue of 
effective functioning of corporations, the quality of corporate governance in the innovative economy is relevant.

A corporation is a group of individuals united by a common interest. A corporation is a subject of economic relations. Modern corporations unite a large number of enterprises, which allows you to concentrate the resources needed to implement innovative projects, access to foreign markets. The consolidation provides both stability and the ability to solve large-scale problems.

The Institute of Corporate Governance in Ukraine is still being formed. The corporate governance system is designed to regulate the relationship between the company's managers and their owners, to coordinate the goals of stakeholders, ensuring the effective operation of the company.

In theory, there are two main models of corporate governance: outsider and insider. The ownership structure distinguishes two corporate governance management systems. Outsider systems are characterized by broad shareholder ownership, the influence of managers to a greater extent on decision-making, the use of various forms of interception of control over the corporation.

Insider management system occurs when the concentration of ownership in the hands of several people who own large parts of corporate assets.

The structure of ownership and the degree of its concentration, the mechanisms of financial regulation, the development of the stock market, legislation contribute to the formation of various systems of corporate governance.

In each country, the corporate governance system is gaining its specific features and characteristics. The basic models of corporate governance are Anglo-American, German, Japanese.

Special features of the Anglo-Saxon model are the high degree of dispersion of share capital and, accordingly, the determining role of control and management; German - a high degree of employee participation in the management of the corporation, the distinguishing features of the Japanese model is the developed practice of cross-ownership of share capital, a high degree of its concentration among medium and large shareholders.

The Ukrainian model of corporate governance is still at the stage of formation and is transitional, in which elements of different models are formally represented, there is a combination of elements of outsider and insider models.

In Ukraine, there is an extremely scattered ownership structure with a great similarity of the Ukrainian model of corporate governance to the German (continental) model. Scattered ownership is a hallmark of the outsider model, the current trend of increasing concentration of ownership is a manifestation of the formation of elements of insider control. The introduction of cross-ownership of shares, the formation of complex corporate structures of various types are inherent in 
the insider model. Financial difficulties affected the intensification of the processes of redistribution and consolidation of property, the concentration of share capital.

Concentration of ownership in various forms is recognized as the main economic mechanism of corporate control, which helps to increase economic efficiency. There is also a concentration of property. The size of assets involved in the corporation determines the level of financial flows, there is income that is weakly related to business efficiency, is incompatible with innovative development. The corporate power of the dominant groups is aimed at income generated by controlling the financial flows of enterprises and even contradicts the goals of the corporation and stakeholders. Withdrawal of income contributes to other types of opportunistic behavior.

The system of participation in the decision-making of employees, the state and business owners is a prerequisite for the development of corporate governance. Stabilization of the institutional environment of the economy will contribute to longterm effective development of corporate capital. A system of incentives and benefits for large businesses involved in innovation will be a determining factor in the development of corporations. Private-public partnership should be recognized as an effective means of concentrating resources on priority areas of innovative development, which will facilitate the introduction of various forms of their implementation.

Improving corporate governance in an innovative economy is an effective tool for business development, attracting investors, increasing competitiveness, entering the world market. The development of corporate business is through innovation. Successful is a corporation that creates innovations, which has a comprehensive view of the innovation process, and this is possible with effective corporate governance. Corporate governance is a way of managing a company that ensures a fair and equitable distribution of performance results among shareholders and other stakeholders. Corporate governance is a way of means and rules that help shareholders control the company's management and influence management in order to maximize the company's profits and value. Corporate governance - a system of relationships between company managers and their owners on issues of ensuring the efficiency of the company and protecting the interests of owners and other stakeholders. Corporate governance is a system of processes and rules that govern the company's behavior in the market.

New opportunities for the flourishing of existing relations in the form of cooperation, the development of integration relations determined the objective preconditions that have developed at the present stage of development of corporate relations, namely: development on purely market principles has determined the need to find ways to improve social relations in society; small production due to high costs 
and the creation of uncompetitive products have become inefficient; most management decisions require significant financial infusions, which can be formed on the principles of consolidation of both financial resources and other reserves of production capacity.

In the new realities, the term corporate governance has come to mean the interaction of a wide range of people in all aspects of the company, including social and image. Under these conditions, the number of management problems that the corporation must solve as an association of people with different interests but common goals is expanding. The leading role of corporate governance in ensuring the stability of financial markets, investment and economic growth is recognized.

The need to build a socially oriented market economy, creating conditions for accelerated innovation, progressive scientific and technological progress through consolidated funds, finding ways to improve the welfare of the population and improve social relations in society have identified the need for corporate governance, pooling finances, small productions. Such development tasks have caused a cooperative and corporate movement in foreign countries.

For Ukrainian business there is a need for quality corporate governance, transparent asset management, proper corporate governance, which makes management accountable.

The World Bank's Doing Business rating influences businessmen's decisions about the feasibility of investing in the country, determines the basic security conditions for investment and protection of business interests, and is an order of an international investor. The final place of the country in the ranking is formed by the ten most important indicators in terms of business prospects, such as business start-up procedures, registration of property rights, taxation, international trade, obtaining loans, securing contractual obligations, protection of minority rights, etc.

Ukraine had the lowest position in the World Bank's Doing Business ranking in 2012 - 152nd place out of 183. In recent years, Ukraine has significantly improved its position in the ranking, rising to 64th place in 2020, as shown in Fig. 1.

This result is not the best even among the countries of the post-Soviet space. Lithuania is in 11th place, Estonia - in 18th, Latvia - in 19th, Kazakhstan - in 25th, Russian Federation - in 28th, Moldova - in 48th, Belarus - in 49th.

According to World Bank experts, five of Ukraine's ten indicators have gained positive changes in Ukraine, namely obtaining building permits, connecting to power grids, registering property, protecting minority investors, and international trade. In Ukraine, legislation is significantly improved, the activities of corporations and relations between their members become more flexible, a culture of civilized corporate relations is formed. 


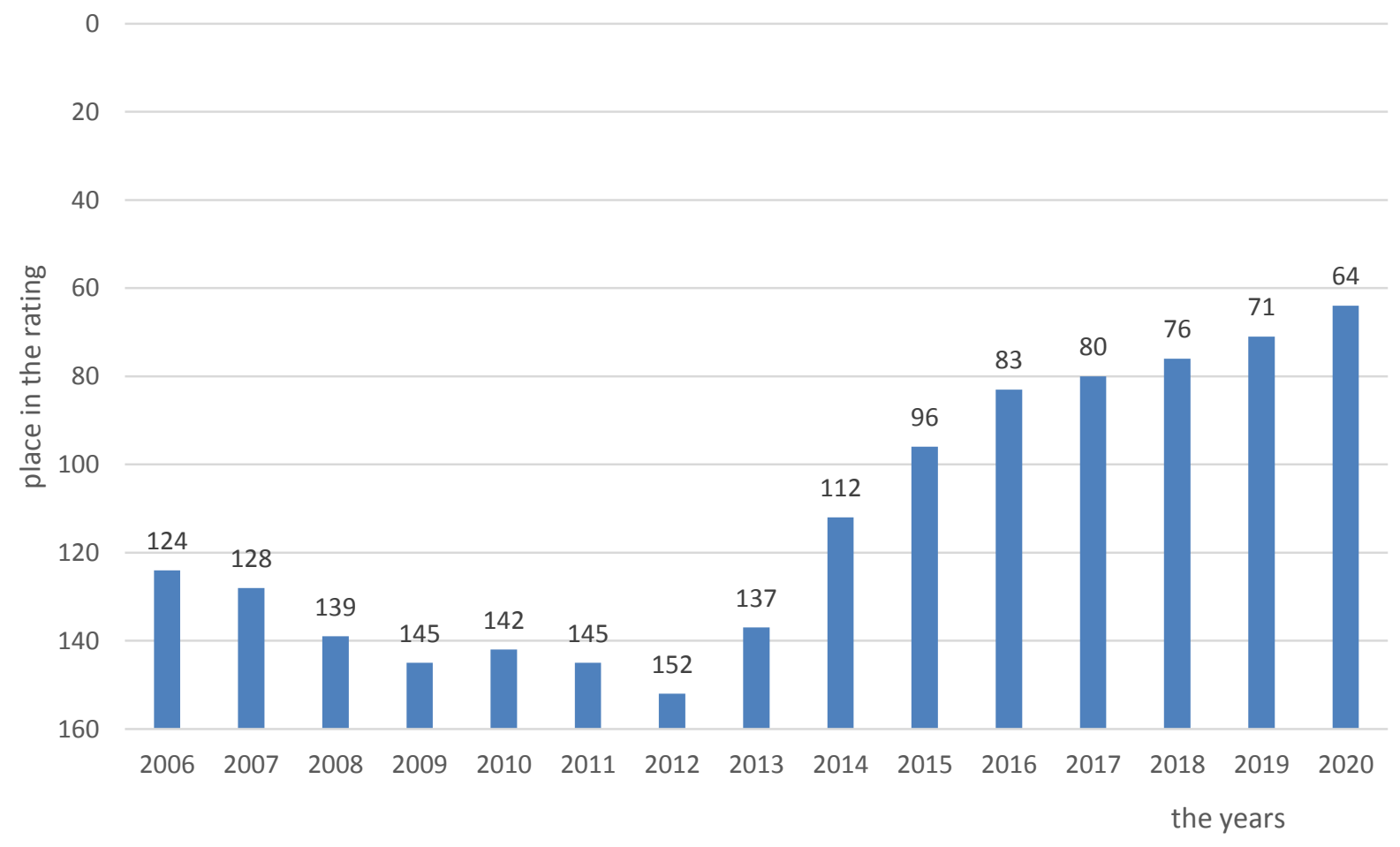

Fig. 1. Ukraine's place in the Doing Business ranking from 2006 to 2020. [developed by the author on the basis of [2]]

Thus, the pace of market relations stimulates the search for appropriate forms of governance that can meet the accelerated development of market competition, which is intensifying in the global economy, aimed at capital competition for production and commercial activities ensuring the efficiency of production.

The quality of corporate governance and an effective system of corporate governance as a condition for the development of international business. Peculiarities of corporate forms of management are independent legal status, share ownership of participants, concentration of managerial functions at the highest level of management.

The corporation is a complex hierarchical structure that requires regular management influence. The two main forms of such influences define corporate management, such as business management and development, and corporate governance, which focuses on establishing mechanisms to ensure accountability and balance of interests of all participants in corporate relations. Ensuring the balance of interests of participants in corporate relations (shareholders, management and stakeholders) is the main purpose of corporate governance. The basic function of corporate governance is to ensure the functioning of the corporation in the interests of owners who provide the company with financial resources. 
Corporate governance, as proposed by the World Corporate Governance Forum, studies the structures and processes for managing and controlling an enterprise. According to the international approach defined by the World Bank, corporate governance includes three basic components: legislation, private sector management practices and regulations that allow to attract financial, human resources, efficient business activities and accumulate long-term economic value by increasing the value of the shareholder. capital, embodying the interests of shareholders and society as a whole.

The main structural components of corporate governance are: the rights of owners (shareholders); governing bodies; disclosure of information; social responsibility of the corporation (business). Within these blocks, the International Leading Corporate Governance Practice (CGBP) is being formed. It is these elements in the interaction are able to provide the basic functions of corporate governance, sustainable development of the corporation.

Corporate governance encompasses the relationship between management, the board of directors (supervisory board), controlling shareholders, minority shareholders and other stakeholders. Accordingly, the three most important bodies of corporate governance are the general meeting of shareholders, the board of directors (supervisory board) and management (board), thus distinguishing in the structure of corporate governance levels of ownership, supervision and control and executive management. The interaction of levels establishes counter-flows of capital movements and transparent reporting.

Separation of ownership, control and management functions creates the socalled "agency problem", high-quality corporate governance by increasing transparency and accountability can reduce asymmetric information and, as a result, prevents the withdrawal of funds and asset appropriation, provides more efficient investment and risk management, improves the results of the company's operating activities.

Good corporate governance does not necessarily imply a strong hierarchy of all decision-making processes, it involves accountability. Strong corporate governance can be in a flat horizontal management structure. Most foreign companies have a horizontal structure of relations and at the same time high-quality corporate governance and accountability. In Ukrainian companies, the force is hierarchy, for the division of responsibilities.

Ukrainian companies need to learn to delegate authority to a wider range of people, the introduction of micro-management is becoming important, to implement experience and knowledge in the decision-making and implementation process.

From the point of view of corporate governance, creditors play a disciplinary role by imposing restrictions on the space for decision-making at the discretion of 
management, setting additional limits on the amount of costs, transfer of assets, the allowed level of risk. In Ukraine, the debt capital market is insignificant and the cost of debt capital for Ukrainian companies is extremely high, apparently due to weak public institutions.

International financial institutions are the only investor that can actually offer debt capital on terms comparable to those of developed economies.

International financial institutions are potential investors of Ukrainian enterprises, which by investing can encourage private investors to invest and as a result reduce the cost of financing for the company. In addition, lenders create additional incentives to maintain a high level of corporate governance.

Investors prefer to invest in companies with a high level of corporate governance by improving the protection of shareholders 'and creditors' rights, especially in countries with weak public institutions. Research conducted by McKinsey \& Company found that most investors in the world are willing to pay a premium to the share price of companies with a high level of corporate governance, the percentage of such investors in all regions of the world is about the same, is 75$78 \%$.

The size of such a premium, depending on the region, ranges from 13 to $30 \%$, corporate governance at the enterprise level weighs more in countries with weak investor protection [3].

A modern company operates in physical and digital reality, must have the ability to develop steadily in the face of adverse external conditions, uses long-term planning as a key element of enterprise success and its main asset is people [4].

The requirements of the main global trends in corporate governance are:

- increasing the role of safety and environmental protection;

- stakeholder interests as the main goal of the company;

- corporate culture and its development;

- a broader view of the variety of Soviets;

- development and growth of investor activity.

Improving the quality of corporate governance will meet the challenges of today's world. Corporate governance of modern enterprises in Ukraine is improving relative to current trends.

Assessing the quality of corporate governance takes into account improving the efficiency of resource potential, increasing productivity, transition to an innovative model of development, which involves the development of a new institutional business environment, infrastructure, improving the efficiency of guarantees, social policy and responsibility. Improving the quality of corporate governance is associated with ensuring the economic interests of corporate entities. 
At insufficient level of quality of corporate management there are: imperfection of personnel policy, inefficient work of managers, underdeveloped corporate culture, improper management of business processes, ignoring of innovative activity. The corporate governance system is an organizational model that provides representation and protection of the interests of investors and shareholders. It can be defined by a set of principles and mechanisms for corporate decision-making and monitoring their implementation.

Its main purpose is to increase the corporation's profits, ensure the sustainability of development in compliance with applicable law, taking into account international standards. The level of achievement of corporate governance goals characterizes the effectiveness of the corporate governance system, its integrity properties and the synergistic effect of the existing system. Building an effective corporate governance system is a complex multi-stage process, the stages of which are:

- development of common principles of the corporation (mission, philosophy of the corporation, etc.);

- defining the basic goals of the company and identifying ways to motivate its owners;

- the choice of organizational structure adequate to the goals.

Corporate governance is determined by the relationship between the participants in the management system and these relationships are different in different countries. They are determined in part by legislation and the regulatory system, in part by voluntary adaptation and, to a greater extent, by the action of market forces. The system of corporate governance depends on legal, regulatory and institutional conditions. Trust-based corporate governance mechanisms that are understandable to the parties to international economic relations and in line with international principles make it possible to take advantage of the opportunities of global capital markets.

Creating the foundations of corporate governance, taking into account specific economic, social, legal and cultural conditions, the development of their own policies by market participants are based on the principles of corporate governance.

Principles of corporate governance:

- promoting the development of transparent and efficient markets, not to contradict the principle of legality, to clearly define the division of responsibilities between the various supervisory, regulatory and law enforcement agencies;

- protection of shareholders' rights and promotion of their implementation;

- ensuring equal conditions for all shareholders, including minority shareholders and foreign shareholders, and providing opportunities for effective protection in the event of a violation of their rights; 
- recognition of the rights of stakeholders, established by law or by mutual agreement, to encourage active cooperation between corporations and stakeholders in the creation of material values and jobs, maintaining the viability of financially stable enterprises;

- ensuring timely and accurate disclosure of information relating to the corporation (financial position, results of operations, ownership and management of the company);

- ensuring strategic management of the company, effective control over the work of the board of directors, as well as the responsibility of the board of directors to the company and shareholders.

These principles underlie the programs of cooperation between countries.

Adherence to the basic principles of corporate governance is a factor in making investment decisions. The system of corporate governance is designed to stimulate participants in corporate relations in the development of strategies for the development of companies, the implementation of which can lead to increased business value.

The corporate governance system should have a division of rights and responsibilities between the parties to the corporate relationship and clear rules for decision-making.

Within the framework of corporate governance, the tasks of. the company, the means for their implementation and control are determined.

The general elements of corporate governance are:

- the company's management system and control over activities;

- a structure that defines the distribution of rights and responsibilities;

- decision rules, limits for achieving goals and control over results.

The parameters for assessing the effectiveness of corporate governance systems are the ownership structure, transparency and availability of information, policies and mechanisms for implementing corporate governance, corporate governance risk management and management system, the degree of ownership and prevention of corporate conflicts, corporate governance history. A quality model of corporate relations should promote the innovative development of corporations, build on quality corporate governance and promote the use of the creative potential of the subjects of corporate relations.

The quality of corporate governance is influenced by: activities on stock exchanges, participation of foreign investors, industry affiliation of the corporation, type of activity, level of innovation, structural proportions of ownership and the share of state participation.

Enterprises, implementing high-quality corporate governance, are able to provide a powerful impetus to the development of the Ukrainian capital market. In 
the study of the quality of corporate governance, ensuring the economic interests of corporate entities, it is important to take into account the factors influencing economic growth and sustainable development.

International corporate governance. Trends in the world economy, namely the concentration of capital, integration of industrial and financial capital, diversification of forms and activities, globalization and internationalization, have identified the problem of adapting the corporate environment to the requirements of international economic relations, new rules of corporate business. Most of the global corporate sector - multinational companies, international companies are a powerful mechanism for influencing international economic relations. International corporations unite national markets, the world economic space, transforming international relations into global ones.

Corporate governance is a form of relationship between shareholders, management and other stakeholder groups. This is a system of management relations formed between the participants of corporate relations, which aims to obtain a synergistic effect on the achievement of goals both from their joint activities and from their relationships with external counterparties. Its essence is to ensure a balance of interests between different groups of stakeholders, compliance with the interests of shareholders and ensuring accountability of management. At the international level, there is a high degree of development of information transparency of corporate business and its social responsibility.

The subjects of corporate governance are the governing bodies of the corporation:

- majority and minority shareholders;

- one-tier and two-tier board of directors;

- senior management.

Relationships between the subjects of corporate relations are the object of its influence. Foreign investment and partnerships with Western firms are factors in the implementation of corporate governance, the implementation of international standards of corporate governance and this determines compliance with the international level of corporate governance.

In the context of globalization and under the influence of integration processes, increased attention to corporate governance, there is a need to universalize the rules and regulations of corporate interaction worldwide, optimize institutional mechanisms for regulating the normalization of corporate relations at the interstate level. Corporate governance has become an important part of a global organizational system that is clearly recognized internationally. International standards and norms of corporate governance are aimed at significantly improving national corporate governance systems. 
Authoritative international organizations have led the development and implementation in business practice of international standards of corporate governance, as generally accepted rules. International organizations, such as the OECD, have developed international corporate governance standards and regulations to simplify the process of creating corporate governance codes. The formation of the institutional basis of corporate governance is laid down in the principles of the Confederation of European Shareholders' Associations, the International Corporate Governance Network, the Organization for Economic Cooperation and Development. The main problems of corporate governance development, the need to build effective mechanisms of corporate governance have intensified the ideas of information openness, transparency, sustainable development, corporate social responsibility. The main criteria recommended by the OECD for inclusion in corporate governance codes are:

- basic bases of formation of bases of corporate management;

- shareholder rights, the main functionality of the owners of organizations;

- equal rights of shareholders;

- the role of other stakeholders in corporate governance;

- the procedure for disclosing information about the activities of the organization, transparency;

- responsibility of the general meeting of shareholders.

The criteria combine all the basic principles of corporate governance, emphasizing the problems of rights and equal treatment of all shareholders and other stakeholders, the role of non-financial stakeholders, disclosure and transparency, the responsibility of the general meeting of shareholders. The system of corporate governance standards consists of:

- international standards;

- national standards (codes of corporate conduct of developed and developing countries, Standards of corporations);

- corporate governance models.

Following international standards in countries with economies in transition is a reserve for creating a favorable investment climate, increasing competitiveness and investment attractiveness, expanding foreign economic relations.

The formation of the structure of corporate governance should be based on the principles recognized by international and domestic activities of the functioning of corporate institutions. The most important are the observance of equality of shareholders' rights, accountability, honesty, transparency and responsibility.

An integral part of the effectiveness of corporate governance is the observance of the rights of owners, accountability of management and supervision of the board of 
directors, a high level of transparency and compliance with the key interests of stakeholders. These basic provisions formed the basis of the basic principles of corporate governance of the OECD, which are grouped into the following consolidated groups:

- providing the foundations of an effective corporate governance structure;

- sphere of property rights (shareholders' rights, equal treatment of all shareholders and key ownership functions);

- institutional investors, securities markets and other intermediaries;

- the role of stakeholders in corporate governance;

- transparency and disclosure of information by corporate structures;

- responsibilities of the board of directors.

The structure of corporate governance must be built in such a way as to promote transparency and fairness of markets, provision and efficient allocation of resources, must meet the requirements of the law [5].

The corporate governance structure must ensure the protection of shareholders' rights, fair and equal treatment of all, the ability to obtain effective compensation for violations of their rights.

Mechanisms for the functioning of institutional investors, the securities market and other intermediaries should promote the development of good corporate governance, and to ensure its effectiveness, regulatory and legal infrastructure should be developed, taking into account the conditions of its operation. A ban on market manipulation is imposed. Regarding the role of stakeholders in corporate governance, the rights of stakeholders under the law or multilateral agreements are recognized, and active cooperation between the corporation and stakeholders in creating wealth, jobs and financially sustainable enterprises is encouraged.

The principles of transparency and disclosure by corporate entities define the requirements for timely and accurate disclosure of information on all matters of the corporation, including financial position, results of operations, ownership and management of the company, and information distribution channels must ensure timely, equitable and non-costly access. users to the required information. The structure of corporate governance should contribute to the strategic management of businesses, ensuring the accountability of the board of directors to the corporation and shareholders, creating mechanisms for effective control over management by the board of directors.

Maximum implementation of the achievements of corporate governance of foreign companies, elements of the International Corporate Governance Best Practices (CGBP), building an effective system of corporate governance in companies will meet the urgent need to improve the management aspects of domestic business. Corporate governance allows you to ensure the sustainable development of 
the corporation, increase value and ensure social responsibility to society. It is necessary to talk about the effectiveness of the corporate governance system and its development.

The system of corporate governance must develop and become more complicated, which will mean the formation of corporate dynamics, which is manifested in changes in the parameters of the elements of the elements of the corporate system. PhICS-model of corporate governance of the company can determine the change of parameters according to the evolution of system elements and this model regulates the implementation of international leading practices of corporate governance, forms a system of corporate governance according to business realities and the need for its development. The key factors of the company's development are the life cycle, investments, control and leadership style, development strategy.

The formation of the institutional environment and development have defined international standards, which include international (national) codes and principles of corporate governance.

The development of corporate governance at the global level is due to the spread of multinational corporations basic elements of corporate culture, requires participants in economic cooperation to voluntarily accept the basic principles as a basis for building an effective model of corporate governance.

Increasing globalization of the world economy and destabilizing trends complicates the development and increases the importance of competent corporate strategies, the effectiveness of management decisions.

The development of the corporate form of economic activity, the formation of corporate governance and theoretical studies of corporate governance have modeled the development trends of companies to the level of multidisciplinary big business with appropriate organizational structures of production and management. Studies of domestic corporate structures note the existence of an outsider model of corporate governance with manifestations of insider implementation mechanisms. In practice, there is significant conflict, fierce competition for control of management, significant management and business risks, heterogeneity and differentiation of the industrial sector.

Diversification and integration processes, the formation of the internal market, the realization of globalization through adaptation to the external environment, consolidated capital and its scale, forms and methods of consolidation are the modern main mechanisms for the formation of corporate entities. Improving and developing corporate governance mechanisms is important primarily for large business structures. 
The main feature of modern corporate governance is the transition to the stakeholder model and consideration of the corporation as a coalition of stakeholders, each of which seeks to realize specific economic interests, corporate governance practice from the standpoint of stakeholder theory is characterized by corporate social responsibility of industrial business. The market value of the company's business is the main indicator of the effectiveness of corporate strategy.

The assessment of corporate governance is based on the relationship of all the required factors, such as the most used are the market value of the business, the effectiveness of a particular strategy, the activities of the company's management. Evaluation is an expression of the quality of corporate governance, assessment of the investment attractiveness of the company and the effectiveness of corporate development.

\section{References:}

1. Druker, P. F. (2003). Zadachi menedzhmenta v XXI veke [Management Challenges for the 21st Century] [Tekst] : uchebnoe posobie / P. F. Druker. - Moskva : Vil'yams. [in Russian]

2. The world bank (2020) Doing Business. Measuring Business Regulations. Retrieved from https://www.doingbusiness.org/en/data/doing-business-score

3. McKinsey \& Company (2002) Governance is unceasingly at the heart of investment decisions, new McKINSEY Survey shows. Investors Eager for Greater Accounting Disclosure, Other Broad Reforms. Retrieved from http://www.mckinsey.com/governance.

4. OECD (2004), OECD Digital Economy Outlook 2017. https://doi.org/10.1787/9789264276284-en

Retrieved from https://read.oecd-ilibrary.org/industry-and-tecnology/oecd-digital-economy-outlook2017_9789264276284-en

5. OECD (2004), OECD Principles of corporate governance. Retrieved from https://read.oecdilibrary.org/industry-and-services/oecd-principles-of-corporate-governance-2004_9789264015999-en. 